\title{
Bimodal zircon ages from Natash volcanics (southeast Egypt) and the link between eruption mechanisms and Late Cretaceous tectonics
}

\author{
Abu El-Rus Mohamed Ali ${ }^{1,}{ }^{*}$, Paquette Jean-Louis ${ }^{2}$, Chazot Gilles ${ }^{3}$, Vannucci Riccardo ${ }^{4}$
}

${ }^{1}$ Assiut Univ, Dept Geol, Fac Sci, Asyut 71516, Egypt.

2 Univ Clermont Auvergne, Lab Magmas \& Volcans, CNRS, IRD,OPGC, F-63000 Clermont Ferrand, France.

3 Univ Brest UBO, IUEM, Geosci Ocean, UMR 6538, PI Copernic, F-29280 Plouzane, France.

${ }^{4}$ Univ Pavia, Dipartimento Sci Terra \& Ambiente, Via Ferrata 1, I-27100 Pavia, Italy.

* Corresponding author : Mohamed Ali Abu El-Rus, email address : aliabuelrus@yahoo.com

\begin{abstract}
:
Trachyte plugs from the Natash volcanic field have been precisely dated using in situ U-Pb geochronology on zircon grains at similar to 93Ma. Available zircon ages thus suggest that the overall volcanic history at Natash was probably shorter than previously estimated based on $\mathrm{Rb}-\mathrm{Sr}$ and $\mathrm{K}-\mathrm{Ar}$ ages, which are more sensitive to element mobility. Basaltic flows and trachyte plugs were produced by a largely synchronous, Upper Cretaceous volcanic activity that occurred in the Natash area at the onset of the extensional fracturing that preceded and accompanied the doming of the Afro-Arabian Shield. Extraction and eruption of volumetrically dominant basalts from deeper lithospheric levels were ruled by major NW-SE strike-slip faults, whereas both major and subordinate fault systems activated by successive tectonic pulses favoured the ascent of more evolved melts (i.e. trachytes and rhyolites) from shallow-level magma chambers. The study revealed also the presence of zircon xenocrysts in some trachyte plugs associated or not to magmatic zircon. These xenocrysts have pre-Cambrian ages (similar to 681Ma) matching those of zircons from basement rocks in the area (similar to $700 \mathrm{Ma}$ ) and were most probably incorporated during the emplacement of trachyte plugs at shallow depths. The strictly bimodal ages recorded by zircons suggest a very large time gap ( $>500 \mathrm{Ma})$ between the end of the Pan-African Orogeny and the onset of new tectono-magmatic activity in the Natash area.
\end{abstract}

Keywords : Eastern Desert Egypt, Cretaceous volcanism, Natash volcanics, Trachyte plugs, U-Pb zircon ages 


\section{Introduction}

Although Upper Cretaceous volcanism in the Natash area (southeast Egypt) has been extensively investigated (Ressetar et al. 1981; Crawford et al. 1984; Mohamed 2001; Endress et al. 2009, 2011; Abu El-Rus et al. 2016, 2018; Abu El_Rus and Rooney, 2017; Khalaf et al. 2018) most geochronologic studies are still limited to bulk-rock Rb$\mathrm{Sr}$ and $\mathrm{K}-\mathrm{Ar}$ ages that are sensitive to alteration. This makes it difficult to decipher the relationships between mafic and more evolved volcanics as a function of tectonic activity and eruption dynamics and to set an overall geodynamic scenario. During our previous field campaign in the Natash field devoted to xenolith and basalt studies (Abu El-Rus et al. 2016, 2018), we sampled trachyte plugs that revealed the presence of both inherited and newly formed zircons suitable for precise in-situ U-Pb dating. The measured ages are presented here and used to discuss the possible geodynamic scenario for Upper Cretaceous volcanism in the Natash area as resulting from the combination of new geochronological evidence and available petrologic and structural information.

\section{Site description}

One of the larger lava fields $\left(\sim 560 \mathrm{~km}^{2}\right.$, Crawford et al. 1984) in the northeast African plate is that of Wadi Natash, which lies $125 \mathrm{~km}$ ENE of Aswan (Fig.1a). The volcanic field occurs at the eastern shoulder of the NW trending Komombo, Nuqra and Kharit rift basins (Madani 2000; Mo'men et al. 2017) and comprises alkali olivine basalts to benmoreites along with acidic (trachyte to rhyolite) terms. The northern part of the volcanic field is dominated by trachytes that lie unconformably on the Precambrian basement rocks. The southern part comprises a series of subhorizontal lava flows (about $525 \mathrm{~m}$ thick), intercalated in several places with the Cretaceous Nubian sandstones. In general, three rock sequences form the Natash volcanic succession; the lower one consists of prevailing pyroclastic and volcanoclastic products, whereas the middle and the upper ones comprise lava flows and cryptodomes/or plugs, mainly of trachytic composition (Abu El-Rus et al. 2016, 2018; Khalaf et al. 2018 and references therein). Many trachyte plugs and domes are intruded through the three basalt flows, particularly in the eastern area (Fig.1b). Sometimes, the plugs are surrounded by high-density, consolidated pyroclastic deposits. The regional westward, low angle $\left(5^{\circ}\right)$ dip shown by flow units and intercalated volcanoclastic tuffs is the result of displacement along NWstriking normal faults.

\section{The investigated samples}

The trachyte plugs are made of massive, aphyric and poorly vesiculated rocks. Trachytes are holocrystalline, dominated by alkali feldspar microphenocrysts arranged in subparallel to feldspar laths in the groundmass. Alkali amphibole occasionally occurs. Fine grained titanomagnetite, apatite. and zircon are common accessories in the groundmass.

Three trachyte samples were analysed. NAT1 is closely associated to the main volcanic field and occurs at the eastern border of main basaltic flows, at the contact with Nubian sandstones and a small outcrop of pre-Cambrian metamorphic rocks, where the two major fault line systems (NW-SW and E-W) cross each other. It contains 
small-size zircon euhedral, colourless (with alternation of oscillatory and sector zoning) crystals (Figure 2). NAT-15 and NAT16 were sampled to the east of basaltic flows, in a sandy area within pre-Cambrian medium to high grade metamorphic rocks. Zircon grains are euhedral, light pink, sometimes large, often elongated and broken with a weakly contrasted oscillatory zoning (Figure 2).

Two more samples were selected for zircon studies. NAT17 comes from the same plug as NAT16; it is a volcanic breccia consisting of crust-derived fragments in a trachytic matrix, probably formed during the explosive event related to the emplacement of the plug. NAT17 contains large, subhedral and pink zircons, which display sector zoned crystals sometimes associated to oscillatory zoned outer rims, with at least one grain containing an inherited core. NAT6 is a gabbroic body sampled from the basement in proximity of basaltic volcanics, far from trachyte plugs. It is a mediumgrained rock with hypidiomorphic texture mostly consisting of hornblende, plagioclase and minor quartz \pm clinopyroxene relics. Apatite, sphene, iron oxides and zircon are common accessories. The large, euhedral and pink zircon crystals display a wellcontrasted oscillatory or sector zoning (Figure 2).

\section{Analytical techniques.}

Several mm-size zircon grains were separated at the Laboratoire Magmas et Volcans (LMV Clermont-Ferrand, France) using standard techniques of crushing and sieving, followed by Wilfley table, magnetic separation and heavy liquids before handpicking under binocular microscope. They were mounted in epoxy disks and ground and polished at $0.25 \mu \mathrm{m}$ to expose crystal interiors. U-Th-Pb isotopic data on zircons were obtained by laser ablation inductively coupled plasma spectrometry (LA-ICPMS) at the LMV using methods already fully described in Hurai et al. (2010) and Paquette et al. (2014). Spot diameters of $27 \mu \mathrm{m}$ were associated to repetition rates of $3 \mathrm{~Hz}$ and fluency of $3.5 \mathrm{~J} / \mathrm{cm}^{2}$ resulting in a spot depth of $10-12 \mu \mathrm{m}$. Data were corrected for $\mathrm{U}-\mathrm{Pb}$ fractionation and instrumental mass bias by standard bracketing with repeated measurements of GJ-1 zircon standards (Jackson et al., 2004), while repeated analyses of 91500 zircon standard (Wiedenbeck et al. 1995) treated as unknown, were independently processed for quality control purpose. Data reduction was carried out with the software package GLITTER ${ }^{\circledR}$ from Macquarie Research Ltd (van Achterbergh et al. 2001; Jackson et al. 2004). Concordia ages and diagrams were generated using calculated ratios and Isoplot/Ex v. 2.49 software package by Ludwig (2001). All isotope data and calculated ages are presented in Table 1.

\section{Results}

Most of the spots for NAT1 zircons plot together with a mean ${ }^{206} \mathrm{~Pb} /{ }^{238} \mathrm{U}$ age of $681 \pm$ $10 \mathrm{Ma}$ (Fig. 3c) and a relatively poor MSWD of 2.1. Three additional points plot discordantly at $595 \pm 11 \mathrm{Ma}$ and might be disturbed by the combination of $\mathrm{Pb}$-loss and high common $\mathrm{Pb}$ contribution, a common feature of the late- to post-orogenic felsic rocks within the Arabian-Nubian Shield (Helba 1997; Lundmark et al. 2012; Abu ElEla et al. 2017). 
NAT15 (18 analyses) and NAT16 (19 analyses) zircons (both centres and rims) yield concordant to discordant points defining lower intercept ages of $92.4 \pm 1.3 \mathrm{Ma}$ (Fig. 3a) and 93.0 $\pm 0.9 \mathrm{Ma}$ (Fig. 3b), respectively. These ages are similar within error limits. When plotting together the whole dataset for both samples $(\mathrm{N}=37)$, the resulting age is $92.6 \pm 0.6 \mathrm{Ma}(\mathrm{MSWD}=1.15)$.

The $37 \mathrm{U}-\mathrm{Pb}$ analyses for zircons from the NAT17 breccia plot along a discordia array with 20 concordant points yielding a mean ${ }^{206} \mathrm{~Pb} /{ }^{238} \mathrm{U}$ age of $681 \pm 6 \mathrm{Ma}$ (Fig. $3 \mathrm{e})$, which is interpreted as the zircon crystallization age. The older concordia age of $770 \pm 16 \mathrm{Ma}$ is related to the occurrence of inherited cores within few zircons. On this ground, the rounded shape of the crystals associated to the $\mathrm{Pb}$-loss may have resulted from a fluid-driven high-temperature event related to the interaction between trachyte magma and basement rocks.

Zircons from NAT6 gabbro provide reliable information on the age of basement rocks in the area. The 30 concordant analyses yield a concordia age of $701 \pm 4 \mathrm{Ma}$ (Fig. 3d). A single inherited core was detected and dated at $737 \pm 23 \mathrm{Ma}$.

\section{Discussion}

The new U-Pb zircon ages for NAT15 and NAT16 samples allow to precisely date the magmatism in the Natash volcanic field at $\sim 93 \mathrm{Ma}$, confirming the upper range of zircon ages ( $\sim 87$ to $92 \mathrm{Ma}$ ) recently obtained on three trachytes (Khalaf et al. 2018). The $93 \mathrm{Ma}$ age is within the range of earlier Upper Cretaceous ages obtained for both Wadi Natash volcanics (basalts and trachytes) and Abu Khrug and El Khafa ring complexes by $\mathrm{Rb}-\mathrm{Sr}$ and $\mathrm{K}-\mathrm{Ar}$ methods, which have significantly lower closure $\mathrm{T}$ and are more sensitive to element mobility. Basalt ages range from $104 \pm 7 \mathrm{Ma}(\mathrm{Rb}-\mathrm{Sr}$; Hashad and El Reedy 1979) to 85.6 \pm 3 Ma (K-Ar; El-Shazly and Krs 1973). Available $\mathrm{K}-\mathrm{Ar}$ ages for trachytes were only slightly younger, ranging between $86 \mathrm{Ma}$ (Ressetar 1979) and $78 \mathrm{Ma}$ (Higazy and El Ramly 1960). Among the various ring complexes of

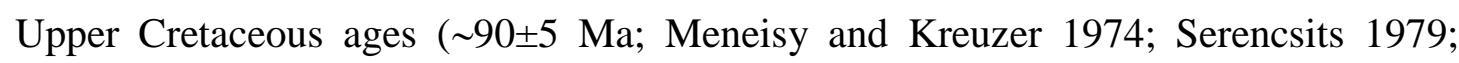
Ressetar et al. 1981), those of El Kahfa and Abu Khrug were intruded at intersections of the main NE-SW, E-W, N-S and NW-SE fault trends (El Gammal et al. 2013), clearly implying a tectonic control for their intrusion. As a whole, new zircon ages indicate that the overall volcanic history at Natash was relatively brief, being eruption times roughly synchronous for both basaltic flows and more evolved melts, although trachytes and rhyolites became probably the dominant products at the end of volcanic activity (Khalaf et al. 2018)

The finding of bimodal (i.e. pre-Cambrian and Upper Cretaceous) zircon ages is also important because they point to a large span of time (>500 Ma) after the PanAfrican Orogeny before the onset of new magmatic activity in the Natash area. Moreover, the occurrence in trachyte plugs of either Upper Cretaceous zircon, associated (sample NAT16) or not (sample NAT15) to separate zircon grains of preCambrian age, or pre-Cambrian zircon xenocrysts only (sample NAT1) is worth considering given the implications for mechanisms of basalt lava and trachyte/rhyolite 
eruption and the overall geodynamic scenario. This requires that magma generation and evolution beneath the Natash area are addressed first.

Available petrographic and geochemical information on more mafic terms of Natash volcanics reveal that none of them is primary melt. All basaltic lavas record various extents of fractional crystallization of olivine, clinopyroxene, plagioclase and spinel, whereas chemical and isotopic overprint caused by assimilation of crust-derived materials seems negligible (Mohamed 2001; Abu El-Rus et al. 2018. Mohamed (2001) suggested that the dominant source component was the asthenospheric, garnet-bearing mantle, favouring an active model wherein melting, melt segregation and rifting were caused by an uprising plume head. In contrast, Abu E-Rus et al. (2018) and Khalaf et al. (2018) concluded that primary Natash melts originated from low $(<5 \%)$ degrees of partial melting of hybrid, amphibole-bearing lithospheric mantle, metasomatized by hydrous fluids during Pan-African Orogeny. This hybrid mantle source underwent thermal erosion and melting in response to upwelling asthenosphere at the onset of the extensional fracturing that preceded the doming of the Afro-Arabian Shield. Whatever the melt source and the proposed geodynamic model, most interpretations point to a crucial role of tectonics in melt generation and emplacement, according to the structural evidence that volcanics are arranged along the NW-SE extensional fault system of the region (Madani 2012; Abu El-Rus et al. 2018), whereas plugs and domes preferentially occur at intersections of the main fault trends of the area (El Gammal et al. 2013). Noticeably, the low magma fluxes recorded at Wadi Natash suggest the existence of multiple short-lived chambers, rather than an individual long-lived chamber, at moderate crustal levels $(<28 \mathrm{~km})$ beneath the volcanic field (Perry et al. 1990, Mohamed 2001). As for more evolved melts (trachytes, rhyolites), field and petrochemical evidence suggest that they formed by extended fractional crystallisation in a high-level magma chambers (Mohamed 2001; Khalaf et al. 2018); nevertheless, some minor role of the crust as contaminant cannot be excluded based on the chemical variability of these evolved melts and the presence of zircon xenocrysts therein.

During the Early Cretaceous rift basins developed in Central and North Africa in response to an extensional stress regime driven by forces that originated with the opening of South Atlantic (Bosworth et al. 2008). These basins formed over a complex set of left-lateral strike-slip faults and ductile shear zones that strike NW-SE across the Precambrian of Arabia and Egypt (Stern 1985). This complex fault system would represent a set of continental transforms developed in response to a major episode of Late Precambrian extensional continental crust formation in northernmost Afro-Arabia (Stern 1985). The Komombo, Nuqra and Kharit rift basins of Early to Late Cretaceous age are part of this geodynamic scenario and appear to be grabens or half-grabens (Madani 2000, 2012; El Gammal et al. 2013; Mo'men et al. 2017) that formed at the onset of the extensional fracturing that preceded and accompanied the doming of the Afro-Arabian Shield (El Rus et al. 2018). Noticeably, morphotectonics and geophysical investigations reveal the presence of a deep basin below the east end of Wadi Natash (El Gammal et al. 2013); moreover, they show that the deepest basement surface in South Eastern Desert lies at about $4700 \mathrm{~m}$ b.s.l. between Wadi Shait and Wadi Natash, with the maximum downthrow at intersections of the major NE and NW faults. 
The repeated upraise of melts along the NW fault system since Late Jurassicearly Cretaceous (Madani et al. 2012) is a strong evidence that faults and shear zones were moved intermittently since the early extensional fracturing of the Afro-Arabian Shield, according to geophysical and structural evidence that highlights the importance of left lateral slip tectonics along NW-SE fault system during early phases of rift development (Cochran and Martinez 1988; Ghebreab 1998; Makris and Rihm 1991; Moustafa 1997). Nevertheless, volumetric observations and the composition of the most primitive lava flows indicate that Natash volcanics represent small volumes of melt entirely produced within the lithospheric mantle at 2.0-2.6 GPa (up to $86 \mathrm{~km}$, Abu El-Rus et al 2018). Since the presence of an uprising (either by active or passive mechanisms) mantle plume beneath the lithosphere in Natash area would lead to the formation of a large igneous province (White and McKenzie 1989; Bown and White 1994; Hopper et al. 2003; Sharma 2005; Sheth 2007), we suggest an alternative model whereby melting of limited sectors of lithospheric mantle is induced by small cells of hot convecting asthenosphere that well up to fill the space generated by the tectonic stretching and thinning of the lithosphere (Fig. 4). Such small-scale asthenosphere cells are commonly proposed in the passive rifting areas (Cochran 1983; Buck 1986). The melt fractions move upward through the deep NW faults and are poured out at surface forming volcanic eruptions during extensional movements.

Fractional crystallisation may occur at various lithospheric levels during each phase of tectonic quiescence thus producing more evolved melts. The upraise and eruption of these latter will occur at the onset of each new pulse of the extensional stress regime. More mafic melts derived from chambers located at deeper or moderate crust levels along major strike-slip faults, as suggested by the close association of basaltic flows with a NW-SE strike-slip fault that marks the eastern shoulder of a rift basin where the deepest basement surface has been detected (El Gammal et al. 2013). In contrast, both major and subordinate faults probably drained more evolved melts from high-level magma chambers thus forming plugs and domes. In this scenario, trachytes and rhyolites were erupted through either conduits (faults) re-activated by extensional tectonics after the ascent of earlier batches of deeper melts or new conduits activated by successive tectonic pulses (Fig. 4). This seems consistent with their occurrence at intersections of the main NE-SW, E-W, N-S and NW-SE fault trends (El Gammal et al. 2013). Zircon xenocrysts of pre-Cambrian age can be regarded as crust fragments taken from the shallow level magma chambers or the conduits; however, given the limited crust contamination of their host lavas, these old zircons were most probably incorporated during the emplacement of trachyte/rhyolite plugs close to the surface, as it is the case of NAT17 breccia.

The reasons for the occasional presence of newly formed ( 93 Ma) zircons in trachyte plugs needs to be finally addressed. This is most probably due to the variability in composition of trachyte melts and the related zircon saturation. Zircon is a common accessory phase particularly in rhyolites, where it mainly occurs within feldspar laths (Mohamed 2001). Using available bulk rock compositions (Ressetar et al. 1981; Mohamed 2001) and the zircon saturation model proposed by Gervasoni et al. (2016), we calculated putative zircon saturation $\mathrm{T}$ values in the range of $830^{\circ}$ to $930^{\circ} \mathrm{C}$ for 
trachytes and $\sim 900$ for average rhyolite. In turn, assuming for rhyolites a $\mathrm{T}$ range of $900-800^{\circ} \mathrm{C}$, a value from 725 down to $400 \mathrm{ppm} \mathrm{Zr}$ is obtained for melt at zircon saturation. This value, observed in most rhyolites, explains the presence of primary zircon in these rocks. The same calculations for trachytes ( $\mathrm{T}$ range from $1000^{\circ}$ to $850^{\circ}$ C) gives values $>1700$ down to $750 \mathrm{ppm} \mathrm{Zr}$ for melt at zircon saturation. These high contents are not commonly reached by trachyte melts that show a wide range of $\mathrm{Zr}$ concentrations (570-1360 ppm) thus explaining the occasional presence of primary zircon in trachyte plugs.

\section{Conclusions}

New in-situ U-Pb zircon ages for trachyte plugs occurring in the Natash volcanic field date the volcanic episode at $\sim 93 \mathrm{Ma}$, at the upper range of zircon ages recently obtained on similar sample ( 87 to $92 \mathrm{Ma}$, Khalaf et al., 2018). As a whole, these zircon ages are considered more precise than previous and older $\mathrm{Rb}-\mathrm{Sr}$ and $\mathrm{K}-\mathrm{Ar}$ ages that are more sensitive to element mobility. Basaltic flows and trachyte plugs are thus regarded as the products of a largely synchronous volcanic event that occurred in the Natash area during Upper Cretaceous, at the onset of the extensional fracturing that preceded and accompanied the doming of the Afro-Arabian Shield. Volcanic eruptions were strongly ruled by tectonic activity. More mafic melts were volumetrically dominant at the onset of volcanic activity and were drained from chambers located at deeper or moderate crust levels by major NW-SE strike-slip faults. In contrast, trachyte/rhyolite plugs and domes become dominant as volcanic activity progressively decreased; they formed by the ascent of more evolved melts from high-level magma chambers through either old conduits that were re-activated by extensional tectonics after the ascent of earlier batches of deeper melts or new conduits activated by successive tectonic pulses. Zircon xenocrysts of pre-Cambrian ages ( $681 \mathrm{Ma})$, similar to those of zircons from basement rocks in the area $(\sim 700 \mathrm{Ma})$, were most probably incorporated during the emplacement of trachyte plugs close to the surface.

\section{Acknowledgement}

The present work is part of the research project "The evolution of Lithospheric mantle beneath Nubian Shield: Evidence from mantle xenoliths from Egypt" financed by the Egypt-France Integrated Activities Program, contract 33, to Abu El-Rus and G. Chazot. The field trip to Natash, south Eastern Desert, was jointly funded by Assiut, ClermontFerrand and Pavia Universities, which are gratefully thanked. A grant to J.-L. Paquette by the Université Blaise Pascal allowed measurements of U-Pb ages on zircons.

\section{References}

Abu El-Ela FF, Abu El-Rus MA, Mohamed MA, Gahlan HA (2017) Cold plutonism in the Arabian-Nubian Shield: evidence from the Abu Diab garnet-bearing leucogranite, central Eastern Desert, Egypt. J Geol Soc London 174:1031-1047. 
Abu El-Rus MA, Chazot G, Vannucci R, Gahlan HA, Boghdady GY and Paquette JL (2016) Softening of sub-continental lithosphere prior rifting: evidence from clinopyroxene chemistry in peridotite xenoliths from Natash volcanic province, SE Egypt. J Volcanol Geoth Res 327:84-98.

Abu El-Rus MA, Chazot G, Vannucci R, Paquette JL (2018) Tracing the HIMU component within Pan-African lithosphere beneath northeast Africa: Evidence from Late Cretaceous Natash alkaline volcanics, Egypt. Lithos 300-301:136-153.

Abu El-Rus MA, Rooney TO (2017) Tertiary volcanic activity of the middle Egypt: a probe for asthenosphere-lithosphere interaction in northeast Africa. Chemical Geology 455, 282-303.

Bown JW, White RS (1994) Variations with spreading rate of oceanic crustal thickness and geochemistry. Earth Planet Sci Lett 121:435-449.

Buck WR (1986) Small-scale convection induced by passive rifting: The cause of uplift of rift shoulders. Earth Planet Sci Lett 77:362-372.

Cochran JR (1983) A model for development of Red Sea. Am Assoc Pet Geol Bull 67: 41-49.

CONOCO (1987) Geological map of Egypt, scale 1:500000. The Egyptian General Petroleum Corporation, Cairo, Egypt.

Crawford WA, Coulter DH, Hubbard HB (1984) The areal distribution, stratigraphy and major element chemistry of the Wadi Natash volcanic series, Eastern Desert, Egypt. J Afr Earth Sci 2:119-128.

El Gammal ESA, Salem SM, Greiling RO (2013) Applications of geomorphology, tectonics, geology and geophysical interpretation of, East Kom Ombo depression, Egypt, using Landsat images. The Egyptian Journal of Remote Sensing and Space Sciences 16:171-187.

El-Shazly EM, Krs M (1973) Paleogeography and paleomagnetism of the Nubian Sandstone, Eastern desert of Egypt. Geol Rundsch 62:212-225.

Endress C, Furman, T and Abu El-Rus MA (2009) Geochemistry of 24 Ma Basalts From Northeast Egypt: Implications for Small-scale Convection Beneath the East African Rift System. American GeopysicalUnion (AGU), USA.

Endress C, Furman T, Abu El-Rus M.AA and Hanan BB (2011) Geochemistry of 24 Ma basalt from NE Egypt. In: Van Hinsbergen, D.J.J., et al. (Eds.), The Formation and Evolution of Africa: A Synopsis of 3.8 Ga of Earth History: Source Components and Fractionation History. Geological Society of London Special Publication 357, 265-283.

Feinstein S, Eyal M, Kohn BP, Steckler MS, Ibrahim KM, Mohd BK, Tian Y (2013) Uplift and denudation history of the eastern Dead Sea rift flank, SW Jordan: Evidence from apatite fission track thermochronometry. Tectonics 32:1513-1528. 
Gervasoni F, Klemme S, Rocha-Júnior ERV, Berndt J (2016) Zircon saturation in silicate melts: a new and improved model for aluminous and alkaline melts. Contrib Mineral Petrol (2016) 171:21. DOI 10.1007/s00410-016-1227-y.

Ghebreab W (1998) Tectonics of the Red Sea region reassessed. Earth Sci Rev 45:144.

Hashad MH (1994) Geochemical characteristics and petrogenesis of phonolite-trachyte plugs associated with Wadi Natash volcanic rocks. Middle East Research Center, Ain Shams University, Earth Science Series 8:131-145.

Helba H, Trumbull RB, Morteani G, Khalil SO, Arslan A (1997) Geochemical and petrographic studies of Ta mineralization in the Nuweibi albite granite complex, Eastern Desert, Egypt. Miner Deposita 32:164-179.

Hopper JR, Dahl-Jensen T, Holbrook WS, Larsen HC, Lizarralde D, Korenaga J, Kent GM, Kelemen P (2003) Structure of the southeast Greenland margin from seismic reflection and refraction data: Implications for nascent spreading center subsidence and asymmetric crustal accretion during N. Atlantic opening. J Geophys Res 108:2269, DOI 10.1029/2002JB001996.

Hurai V, Paquette J, Huraiová M, Konečný P (2010) Age of deep crustal magmatic chambers in the intra-Carpathian back-arc basin inferred from LA-ICPMS U-Th- $\mathrm{Pb}$ dating of zircon and monazite from igneous xenoliths in alkali basalts. J Volcanol Geothermal Res 198:275-287.

Jackson SE, Pearson NJ, Griffin WL, Belousova EA (2004) The application of laser ablation-inductively coupled plasma-mass spectrometry to in situ U-Pb zircon geochronology. Chemical Geology 211:47-69.

Jaffrey AH, Flynn, KF, Glendenin LE, Bentley WC, Essling AM (1971) Precise measurement of half-lives and specific activities of $235 \mathrm{U}$ and 238U. Physical Review C4:1889-1906.

Khalaf EAH, Sano T, Tsutsumi Y (2018) Evolution of monogenetic rift-related alkaline magmatism in south Egypt: Insight from stratigraphy, geochronology, and geochemistry of the Natash volcanics. J Afr Earth Sci 147:450-476.

Lundmark AM, Andresen A, Hassan MA, Augland LE, Boghdady GY (2012) Repeated magmatic pulses in the East African Orogen in the Eastern Desert, Egypt: An old idea supported by new evidence. Gondwana Res 22:227-237.

Madani AA (2000) Geological Studies and Remote Sensing Applications on Wadi Natash Volcanics, Eastern Desert, Egypt. Ph.D. Thesis, Faculty of Science, Cairo University.

Madani AA (2012) Discrimination of Jurassic Volcanicity in Strike-Slip Basin, Jabal Al Maqtal Area, South Eastern Desert, Egypt, Using ASTER and Field Data. JAKU: Earth Sci 23(2):1-18. 
Makris J, Rihm R (1991) Shear controlled evolution of the Red Sea: pull-apart model. Tectonophysics 198:441-466.

Meneisy MY, Kreuzer H (1974) Potassium-argon ages of Egyptian basaltic rocks. Geologisches Jahrbuch 9:33-39.

Mohamed FH (2001) The Natash alkaline volcanic field, Egypt: geochemical and mineralogical inferences on the evolution of a basalt to rhyolite eruptive suite. $\mathbf{J}$ Volcanol Geotherm Res 105:291-322.

Mo'men A, Darwish M, Abdelhady A, Mahmoud A Essa (2017) Structural and lithostratigraphic evolution of Al Baraka Oil field, Komombo Basin, Upper Egypt as deduce from 2D seismic lines and well logging data. Journal of Basic and Environmental Sciences 2:149-169.

Moustafa AR (1997) Controls on the development and evolution of transfer zones: the influence of basement structure and sedimentary thickness in the Suez rift and Red Sea. J Struct Geol 19:755-768.

Paquette, JL, Piro JL, Devidal JL, Bosse V, Didier A (2014) Sensitivity enhancement in LA-ICP-MS by $\mathrm{N} 2$ addition to carrier gas: application to radiometric dating of UTh-bearing minerals. Agilent ICP-MS journal 58:4-5.

Ressetar R, Nairn AEM, Monrad JR (1981) Two phases of Cretaceous \pm Tertiary magmatism in the Eastern Desert of Egypt: paleomagnetic, chemical and $\mathrm{K} \pm \mathrm{Ar}$ evidence. Tectonophysics 73:169-193.

Serencsits CM, Faul H, Foland KA, El Ramly MF, Hussein AA (1979) Alkaline ring complexes in Egypt: their ages and relationship to tectonic development of the Red Sea. Ann Geol Serv Egypt 9:102-116.

Sharma KK (2005) The Malanima gmatism: an extensional lithospheric tectonic origin. In: Foulger GR, Natland JH, Presnall DC, Anderson DL (eds), Plates, Plumes and Paradigms. Geol Soc Am Spec Pap 388:463-476.

Sheth HC (2007) Large Igneous Provinces (LIPs): Definition, recommended terminology, and a hierarchical classification. Earth Sci Rev 85:117-124.

Stern R (1985) The Najd Fault System, Saudi Arabia and Egypt: A Late Pre-cambrian rift-related transform system? Tectonics 4:497-511.

van Achterbergh E, Ryan CG, Jackson SE, Griffin WL (2001) Data reduction software for LA-ICP-MS. In Laser ablation-ICPMS in the earth science. P. Sylvester (ed) Mineralogical Association of Canada 29:239-243.

White RS, McKenzie DP (1989) Magmatism at rift zones; the generation of volcanic continental margins and flood basalts. J Geophys Res 94:7685-7729. 